\title{
Epistemology of the southern hemisphere and dentistry
}

\author{
Epistemologías del sur y odontología
}

\author{
Ebingen Villavicencio-Caparó, ${ }^{*}$ María Cristina Alvear-Córdova ${ }^{\S}$
}

In the XVI th century of our era, la Malinche and Felipillo were characters from Mexico and Peru respectively, both of them supported the Spanish invaders in their colonizing efforts; they represent the autochthonous character who prefers everything foreign, perhaps due to a supposition that what is foreign is better than one's own.

The epistemologies of the south (TEOS) are a set of ideological postures which have been developed in South America from the decade of 1980 onwards. They purport the aim of the emancipation of thought, culture and research, they contrast their discoveries to the euro-central perspective which in general dominated science, philosophy and humanities. This trend has also been called a decolonizing twist (spin).

Sergio de Zubiría, a Colombian philosopher, cited Boaventura de Santos saying "History is always told by the hunter, what a difference it would make if history was told by the leopard". ${ }^{1} \mathrm{He}$ mentions he agrees with matters proposed by the Mexican professor Enrique Dussel: "Global social justice is only possible when there is global cognitive justice". ${ }^{2}$ This means that inequalities between knowledge value (worth) of victors (colonizing countries) and defeated (winners and losers) perpetuates this disadvantageous relationship, and does not allow for generation of justice.

Globalization, which took place after the cold war, left as a consequence hegemonic thinking of school of thoughts belonging to victor countries, with the concomitant disappearance of alternate knowledge. From that moment onwards, only the victor's point of view was considered valid, complemented with the desire of a culturalization of developing countries. Consequently there is the perception that everything imported, everything coming from other «first world" countries is better than what is national, as much in technology objects as in cognitive matters. ${ }^{2}$

Current day science banished all ancestral knowledge, because it cannot formulate the problems posed by this knowledge. It underestimated them, as if this type of knowledge were not important, and stigmatized them calling them superstition, subjective beliefs or opinions; nevertheless, in an outburst of double morality, it condescendingly allowed manufacture of constructs (example: quality of life related to oral health), ${ }^{3}$ elaboration of aesthetic patterns (example: smile design, orthodontics diagnosis) which strives to lead the patients towards a European-type universal, standardized, post-modern, deterministic and mechanistic aesthetics model. ${ }^{4}$

Repercussion of TEOS has been mainly observed in literature, with representatives such as Mario Vargas Llosa, Gabriel García Márquez and Julio Cortázar. It also influenced in South American painters, where we have painters such as Oswaldo Guayasamín, Francisco de Szyszlo, Fernando Botero, among others. In the realm of ethics and theology we observe TEOS contribution with Leonardo Booff, Gustavo Gutiérrez, Eduardo Arens who proposed a theological countercurrent by interpreting Christian doctrine from the impoverished reality of South American populations. Likewise, in worldwide epistemology, we can mention Mario Bunge, Orlando Fals Borda, Aníbal Quijano, in Research Methodology we can mention professor Roberto Hernández Sampieri and Elia B Pineda, who are authors of most widespread books in research.

With respect to dentistry, there were universities considered as South American beacons for academic development, such as the Universidad Nacional Mayor de San Marcos (Doyenne in America), University of Buenos Aires, Universidad Javeriana

\footnotetext{
* PhD, Dental Specialist, Dental Research Coordinator.

$\S$ Specialist in Dentistry, Periodontics Teacher, Dental School.

Catholic University of Cuenca.
}

C 2017 Universidad Nacional Autónoma de México, [Facultad de Odontología]. This is an open access article under the CC BY-NC-ND license (http://creativecommons.org/licenses/by-nc-nd/4.0/).

This article can be read in its full version in the following page: http://www.medigraphic.com/facultadodontologiaunam 
(Javeriana University), San Andres National University. Their legacy has been observed in the creation of curricula meshes adapted to local reality. Nevertheless, after the fall of the Berlin wall, with advent of globalization and the concept of worldwide village, a pattern standardization phenomenon in almost all human being's endeavors, going from ways of thinking to modes of action has been observed. This represented an extremely dangerous phenomenon, since it depersonalizes, removes the identity of nations, and pretends to have a Eurocentric model for everyone, to dictate what is and is not acceptable. ${ }^{5}$

Nevertheless, there is already exhaustion among Southern intellectuals with respect to Eurocentric thought. This could be attributed to the European financial crisis of 2008-2014, to the penalty measures applied to Greece, Ireland, Portugal and Spain, which decreased social and labor rights. ${ }^{6}$ Even though Europe has for five centuries taught the rest of the world matters of economics, politics, and democracy, one has the impression that Europe no longer has anything to teach, and it is our turn to invent the future together. Nevertheless, their inability to learn from the new world and recognize us as peers invites reciprocity. Their epidemiological indicators for example, caries experience measured through DMFT (decayed, missing, filled teeth) leads us to think they lack a solution for the problem of greater prevalence in the world, since dental caries is still the greatest health problem in industrialized countries, affecting $60-90 \%$ of all school-age children, according to official data from the Oral Health Program of the World Health Organization (WHO). ${ }^{7}$ In no way would this mean to ignore the meaningful social, cultural, financial and scientific legacy of the Northern Countries, on the contrary, it means going hand in hand as peers, it means to acknowledge their contribution under a critical perspective and then adjust it to reality, it means to assert the value our ancestral knowledge, to revalue or gregarious family sense and even to share our aesthetic perception in the arts.

Great technological advances in oral rehabilitation and orthodontics, still not included in most health systems worldwide (as a right of the patient attending public health services) suggest that dentistry incurs in a social debt towards the community, as proposed by Peruvian, oral health educator Roberto Beltran-Neira. ${ }^{8}$ This begs the legitimate question: in countries where tooth brushing in children has not yet achieved to be implemented as a self-care skill, is it opportune to conduct research on implantology, self-ligating brackets or rare diseases? Are we not falling into the wish to conduct research with the sole purpose of appearing in institution-requested impact factor rankings, in order to obtain credits, or due to mere vanity, overlooking the clear macro objective of responding with research our country's requirements and priorities?

Presently, medicine based on evidence (MBE) has become fashionable; it represents an entirely positivist approach, a partial look into the process of health and disease, with great influence of economist planning. ${ }^{9,10}$

Social Medicine is an example of great strides in Latin America, its main promoters were the Mexican Juan César García and the Ecuadorian Miguel Márquez. This social medicine targets mainly the analysis of health concerns from the perspective of social classes, and not the demographic characteristics normally observed by public health inherited from John Snow's epidemiology. ${ }^{10}$

The task achieved by Argentinians Mario Eduardo Figún and Ricardo Rodolfo Garriño is monumental. They completed the treatise "Anatomía odontológica" (Dental anatomy) from which South American dentists have drawn knowledge for the last 20 years.

The book "Neurofisiología de la oclusión" (Neurophysiological aspects of occlusion) written by Enrique Echeverry Guzmán and Gisela Sencherman de Savdieis extremely didactic. Likewise, professor Arturo Manns has recently conglomerated notes from courses he taught in Chile and has converted them into a "Manual de oclusión» (Occlusion manual), which brilliantly exhibits practice and teaching abilities. We couldn't but mention the internationally recognized Argentinian Fermín Carranza, author of «Periodoncia clínica" (Clinical periodontics) or Guillermo Romanelli of the same nationality.

Another important professor was Guillermo a Ries Centeno, author of the book "Cirugía bucal» (Oral surgery) which has been used by over five generations of South American dentists; from him we have learned surgical technique. When reviewing theses on dental caries, the most cited author is the Peruvian Gilberto Henostroza with his book "La caries dental» (The dental caries).

Ecuador is an example of assistance to patients with disabilities. Peru, Venezuela, Colombia, Argentina and Brazil have free full prostheses programs for subjects in extreme poverty circumstances. We cannot but mention Colombia, in its Antioquia municipality, which has been the harbinger of oral health promotion and prevention. It is also worth mentioning the great influence of the Brazilian Biological School, as the present Mecca of Dentistry. 


\section{REFERENCES}

1. De Zubiría-Samper S. Conferencia investigación acción participativa y epistemologías del sur. Cátedra Libre Martín Baró [Video File]. 2013. [Cited 2017 January 15] [1:31:32 min]. Available in: https://www.youtube.com/watch?v=lyKekZISnUY

2. Dussel E. Grosfoguel y Dussel - Descolonización y geopolítica del conocimiento - UNAM [Video File]. 2012. [Cited 2017 January 3] [1:39:36 min]. Available in: https://www.youtube. com/watch?v=mySCGIdLXQU

3. Gherunpong S, Tsakos G, Sheiham A. Developing and evaluating an oral health-related quality of life index for children; the CHILDOIDP. Community Dent Health. 2004; 21 (2): 161-169.

4. Sarabia-Aguilar JA. Ortopedia maxilar [Internet]. 2009 [Cited 2017 January 30]. Available in: http://www.amom.com.mx/ amominfo36.htm

5. Eco U. Apocalípticos e integrados. 7a ed. Madrid: Lumen; 1984.

6. Ramonet I. Sadismo económico. Le Monde diplomatique en español. 2012; 201: 1-2.
7. Petersen PE. The World Oral Health Report 2003: continuous improvement of oral health in the 21st century-the approach of the WHO Global Oral Health Programme. Community Dent Oral Epidemiol. 2003; 31 Suppl 1: 3-23.

8. Beltrán-Neira R. Deuda social de la odontología. Rev Estomatol Herediana. 2011; 21 (3): 175-178.

9. Ortega-Calvo M, Cayuela-Domínguez A. Medicina basada en la evidencia: una crítica filosófica sobre su aplicación en atención primaria. Rev Esp Salud Pública. 2002; 76 (2): 115-120.

10. Breilh J. La epidemiología crítica: una nueva forma de mirar la salud en el espacio urbano. Salud Colectiva. 2010; 6 (1): 83-101. 